\title{
Atypical presentation of large intracranial epidermoid tumour in a child
}

\author{
Ethan G Chuang, ${ }^{1}$ Denise Malicki, ${ }^{2}$ Michael Levy, ${ }^{3}$ John Ross Crawford ${ }^{4}$
}

'Bishop's School, La Jolla,

California, USA

${ }^{2}$ Pathology, Rady Children's

Hospital University of California

San Diego, San Diego,

California, USA

${ }^{3}$ Neurosurgery, University of

California San Diego, San Diego,

California, USA

${ }^{4}$ Neurosciences and Pediatrics, University of California San Diego, San Diego, California, USA

Correspondence to Dr John Ross Crawford; jrcrawford@ucsd.edu

Accepted 18 July 2021
Check for updates

(C) BMJ Publishing Group Limited 2021. No commercial re-use. See rights and permissions. Published by BMJ.

To cite: Chuang EG,
Malicki D, Levy M, et al. BMJ
Case Rep 2021;14:e244311.
doi:10.1136/bcr-2021-
244311

\section{DESCRIPTION}

A 16-year-old boy with negative past medical history presented to an outside hospital with a first time right-sided focal seizure. Neurologic examination at presentation was normal. CT performed in the emergency room revealed a large left intra-axial cerebral mass without haemorrhage (figure 1A). Subsequent MRI demonstrated a large $7.5 \mathrm{~cm}$ well-circumscribed intra-axial mass within the left cerebral hemisphere with minimal enhancement and surrounding oedema (figure 1B-F). T2 shinethrough artefact on diffusion-weighted imaging was initially misinterpreted as demonstrating reduced diffusivity, suggestive of hypercellularity, and highgrade histology. The differential diagnosis based on the MRI features included high-grade glioma, atypical teratoid/rhabdoid tumour, embryonal tumour, or anaplastic ependymoma. Atypical intra-axial epidermoid tumour, complex neuroepithelial cyst, or low-grade glioneuronal tumour were considered less likely diagnostic considerations. No fat density or calcifications were present on CT to suggest teratoma or dermoid cyst.

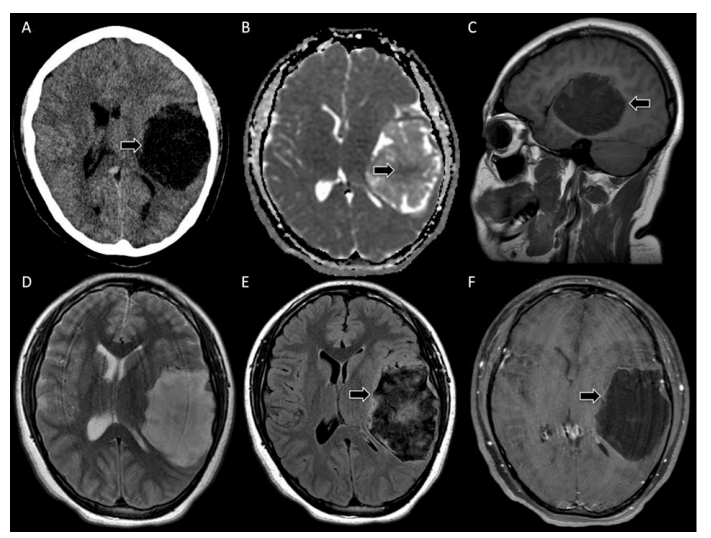

Figure 1 Neuroimaging features of epidermoid tumour. (A) Unenhanced CT demonstrates large irregular but welldefined hypodense mass along the left Sylvian region (arrow) with mass effect and rightward midline shift. (B) Apparent diffusion coefficient map depicts predominantly atypical hyperintense increased diffusivity with only small central area of hypointense reduced diffusivity (arrow). (C) Unenhanced T1-weighted MRI shows T1-hypointensity (arrow). (D) T2-weighted MRI demonstrates homogenous hyperintensity. (E) Fluid-attenuated inversion recovery demonstrates heterogenous unusual hypointensity (arrow) without surrounding T2-hyperintense oedema. (F) Post-contrast (gadolinium) T1-weighted MRI reveals minimal peripheral linear enhancement, which likely reflects displaced adjacent vessels (arrow).

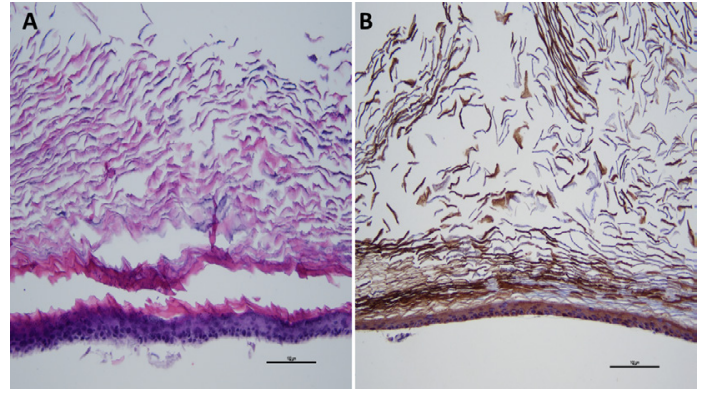

Figure 2 Neuropathologic features of epidermoid tumour. H\&E stained section (A) demonstrates abundant keratin material with keratinised squamous epithelium along lining of cyst that was positive for pan-cytokeratin staining by immunohistochemistry (B) consistent with a diagnosis of epidermoid tumour.

The patient underwent successful left craniotomy and gross total resection of large pearly white flaky tumour mass with thin translucent white membrane and areas of marginal mottled friable tissue. The membrane was adherent to the brain parenchyma. Neuropathology demonstrated no malignancy but abundant keratin with squamous epithelial lining that was positive for pan-cytokeratin by immunohistochemistry consistent with a diagnosis of epidermoid tumour (figure 2A-B). The patient suffered transient post-operative aphasia that lasted 3 days with full recovery. There is no evidence of recurrent disease 12 months after diagnosis and he remains seizure free with a normal neurologic exam more than 1 year after diagnosis.

Epidermoid cysts are benign complex cystic insinuating tumours which arise from abnormal ectodermal cell rests from embryogenesis. They grow slowly by desquamation of epithelial cells and accumulation of keratin and cholesterol. ${ }^{1}$ Less than $2 \%$ of intracranial tumours are reported as epidermoids which are encountered even less commonly in children. Most cases occur in the posterior fossa, and especially the cerebellopontine angle. Supratentorial intracerebral locations account for less than $1.5 \%$ of epidermoids but may be more common in children. ${ }^{12}$ Children most commonly present with headache but normal neurologic examination. ${ }^{2}$ On CT, epidermoids may appear identical to arachnoid cysts. On MRI, they characteristically exhibit isointense or mildly hyperintense signal on T1-weighted images, and hyperintensity on T2 and fluid- attenuated inversion recovery (FLAIR) sequences. Reduced diffusivity on diffusion-weighted imaging (DWI) is regarded as pathognomonic due to restriction of free motion of 
water molecules by the concentric keratin layers. ${ }^{3}$ Interestingly, our case does not exhibit this specific MRI feature unlike all reported in the only series exclusively limited to paediatric intracranial epidermoids. ${ }^{2}$

Complete neurosurgical resection can be challenging with postoperative risks of stroke, cranial neuropathies, chemical meningitis (due spillage of cyst contents), hydrocephalus, and $24 \%$ risk of recurrence. ${ }^{45}$ Less than 50 cases of extremely rare

\section{Learning points}

- Epidermoid tumours are benign neoplasms rarely seen in children. They are typically found as extra-axial posterior fossa masses with reduced diffusivity on diffusion weighted imaging and apparent diffusion coefficient map, and hyperintensity on fluid-attenuated inversion recovery (FLAIR) sequence on MRI.

- We report a highly unusual paediatric case of epidermoid presenting as a large intracerebral mass with significant mass effect, and very atypical increased diffusivity and FLAIRhypointensity on MRI.

- Lack of surrounding vasogenic oedema despite significant mass effect, and hypodensity of mass on CT should encourage inclusion of epidermoid as a differential consideration despite atypical intra-axial location and atypical MRI features. malignant degeneration of intracranial epidermoids into squamous cell carcinoma have been reported with only one in a child. ${ }^{6}$ Our case highlights the diversity of MRI findings associated with intracranial epidermoid tumours.

Contributors EGC was responsible for the design and writing of the manuscript. DM was responsible for the design and writing of the manuscript. ML was responsible for the design and writing of the manuscript. JRC was responsible for the design and writing of the manuscript.

Funding The authors have not declared a specific grant for this research from any funding agency in the public, commercial or not-for-profit sectors.

Competing interests None declared.

Patient consent for publication Parental/guardian consent obtained.

Provenance and peer review Not commissioned; externally peer reviewed.

\section{REFERENCES}

1 laconetta G, Carvalho GA, Vorkapic P, et al. Intracerebral epidermoid tumor: a case report and review of the literature. Surg Neurol 2001;55:218-22.

2 Ahmed I, Auguste KI, Vachhrajani S, et al. Neurosurgical management of intracranial epidermoid tumors in children. Clinical article. J Neurosurg Pediatr 2009;4:91-6.

3 Chen S, Ikawa F, Kurisu K, et al. Quantitative Mr evaluation of intracranial epidermoid tumors by fast fluid-attenuated inversion recovery imaging and echo-planar diffusionweighted imaging. AJNR Am J Neuroradiol 2001;22:1089-96.

4 Sutiono AB, Sidabutar R, Pareira ES, et al. Characteristics intracranial epidermoid cyst between two Hospital from developed vs developing institution and literature review. Interdisciplinary Neurosurgery 2019;18:100500.

5 Akar Z, Tanriover N, Tuzgen S, et al. Surgical treatment of intracranial epidermoid tumors. Neurol Med Chir 2003:43:275-81.

6 Roh TH, Park YS, Park YG, et al. Intracranial squamous cell carcinoma arising in a cerebellopontine angle epidermoid cyst: a case report and literature review. Medicine 2017;96:e9423.

Copyright 2021 BMJ Publishing Group. All rights reserved. For permission to reuse any of this content visit

https://www.bmj.com/company/products-services/rights-and-licensing/permissions/

BMJ Case Report Fellows may re-use this article for personal use and teaching without any further permission.

Become a Fellow of BMJ Case Reports today and you can:

- Submit as many cases as you like

- Enjoy fast sympathetic peer review and rapid publication of accepted articles

Access all the published articles

Re-use any of the published material for personal use and teaching without further permission

Customer Service

If you have any further queries about your subscription, please contact our customer services team on +44 (0) 2071111105 or via email at support@bmj.com.

Visit casereports.bmj.com for more articles like this and to become a Fellow 